Journal of Finance and Banking Review

Journal homepage: www.gatrenterprise.com/GATRJournals/index.html

J. Fin. Bank. Review 2 (1) 38 - 43 (2017)

\title{
Development and Shari'ah issues of the Takaful industry in Malaysia - Effects of the Regulatory Framework on the Implementation and Growth
}

\author{
Muhamad Badri Othman* \\ Faculty of Economics and Muamalat, Universiti Sains Islam Malaysia, Malaysia
}

\begin{abstract}
Objective - This paper aims to discuss and analyse whether the participation of long established conventional insurance conglomerates will be positive towards the development of the Takaful, particularly in the aspect of the operators' compliance towards Shari'ah requirements.

Methodology/Technique - The study reviews literature in related area.

Findings - Findings indicate that the merger and acquisition (M\&A) which have taken place recently by other foreign insurers with our local Takaful operators show that the growth of this industry is promising for years to come for the foreign insurers to tap into our Takaful market.

Novelty - The study attempts to provides insight on effect of foreign companys' merger and acquisition strategies in Takaful market.

Type of Paper: Review
\end{abstract}

Keywords: Islamic finance; Islamic Financial Services Act 2013; merger and acquisition; Shari'ah compliance; Takaful. JEL Classification: G22, K23.

\section{Introduction}

Insurance or Takaful has become an integral part of modern life. In the industrialized society, very few people live without being involved in the insurance transaction (Hashim et al., 2005). Islamic Cooperative Insurance or Takaful has been established and considered a legitimate alternative to Commercial Insurance by a decision issued by the Islamic Jurisprudence Council. Consequently, it has been necessary to develop different ways to deal with Cooperative Insurance and to draw up a new broad perspective for it. This will allow the establishment of Islamic insurance companies, whereby Cooperative Insurance becomes the basis for their businesses and transactions (Mulhim \& Sabbagh, 2010). Takaful industry has shown tremendous growth and accepted worldwide, particularly in Malaysia since the inception and commencement of operations of the first Takaful operator company, Syarikat Takaful Malaysia Berhad (STMB) in August 1985. Since then, Malaysia's Takaful industry has gained momentum and increasingly recognized as a significant contributor to

\footnotetext{
* Paper Info: Received: January 14, 2017

Accepted: March 9, 2017

* Corresponding author:

E-mail: muhamadbadri.othman@yahoo.com, addujaa1632@gmail.com

Affiliation: Faculty of Economics and Muamalat, Universiti Sains Islam Malaysia, Malaysia
} 
Malaysia's overall Islamic financial system. The development of the Takaful industry in Malaysia in the early 1980s was inspired by the prevailing needs of the Muslim public for a Shari'ah-compliant alternative to conventional insurance, as well as to complement the operation of the Islamic bank that was established in 1983. It was, to a large extent, triggered by the decree issued by the Malaysian National Fatwa Committee, which ruled that life insurance in its present form is a void contract due to the presence of the elements of Gharar (uncertainty), Riba' (usury) and Maisir (gambling).

According to Bank Negara Malaysia (BNM)'s website, as of 2007, the total assets of Malaysia's Takaful industry amounted to USD2.8 billion, with market penetration of 7.2\%. Takaful assets and net contributions experienced strong growth with an average annual growth rate of $27 \%$ and $19 \%$ respectively from 2003 to 2007. Globally, the Takaful industry has been growing rapidly, appealing to both Muslims and non-Muslims. The industry is expected to grow by 15-20\% annually, with contributions expected to reach USD7.4 billion by the end of this year. Currently, there are more than 110 Takaful operators worldwide.

\section{Overview of the development of Takaful industry in Malaysia}

Up until 33 years ago, both Muslims and non-Muslims had only one means of insurance protection, that is, via the conventional insurers. Malaysia has achieved significant milestones in the development of its Takaful industry. With the enactment of the Takaful Act 1984, the first Takaful company was established in 1985. Since then, Malaysia's Takaful industry has gained momentum and increasingly recognized as a significant contributor to Malaysia's overall Islamic financial system (BNM, 2015). The total number of Takaful operators increased from eight in 2007 to eleven in 2011.

According to Ernst \& Young's Global Takaful Insight 2013, Malaysia is leading into Takaful market contributions. Malaysia currently holds a 71\% share of ASEAN Takaful contributions (Ernst \& Young, 2013). In 2012, Malaysia's Takaful industry grew strongly by $21 \%$. The rapid liberalization of Malaysia's Islamic finance industry has attracted and encouraged foreign institutions' participation in Malaysia, thus creating a diverse and growing community of domestic and international Takaful operators. There are currently twelve (12) Takaful and four (4) retakaful operators, with five foreign participations from the United Kingdom, Canada, Bahrain, Germany, Singapore, and Japan. These Takaful operators conduct both domestic and foreign currency business. Malaysia continues to progress and build on the industry's rapid development by inviting financial institutions across the world to establish Takaful and retakaful operations in Malaysia to conduct foreign currency business.

In recent years, we have witnessed a number of significant insurance deals across the ASEAN countries. These deals have been inter-industry, including insurance companies, Takaful companies, brokers and special purpose vehicles for holding groups. The Takaful industry has been expanding, but we have been experiencing an influx of mergers and acquisitions (M\&A) resulting in more foreign insurers tapping into the Takaful market which is already populated by many foreign players. For example, AIA AFG Takaful Berhad is a joint-venture company between AIA Berhad and Alliance Bank Malaysia Berhad, a wholly owned subsidiary of Alliance Financial Group Berhad. Sun Life Malaysia (Sun Life Malaysia Assurance Berhad and Sun Life Malaysia Takaful Berhad) is a joint venture by Sun Life Financial Incorporated of Canada and Khazanah Nasional Berhad. The centrepiece of Sun Life Malaysia's distribution strategy is its exclusive Bancassurance agreement with CIMB Bank in Malaysia whereby it is able to distribute its products and services through the Bank's extensive network of branches nationwide.

Other examples include AIA Public Takaful Berhad (formerly known as ING Public Takaful Ehsan Berhad) is jointly owned by AIA Group (AIA), Public Bank Berhad (PBB) and Public Islamic Bank Berhad (PIBB) with an equity participation of $60 \%, 20 \%$, and $20 \%$, respectively. While Great Eastern Takaful Berhad (formerly known as Great Eastern Takaful Sdn Bhd) is a joint venture company between I Great Capital Holdings Sdn Bhd (i-Great), a subsidiary of Great Eastern Holdings Limited and Koperasi Angkatan Tentera (Malaysia) Berhad. The merger and acquisition (M\&A) in Takaful industry show that foreign insurance companies are interested in tapping into Takaful market in Malaysia to grab the opportunities with a promising 
sector. This is because the Asian region has majority Muslim populations and thus proves to be a great potential for Islamic finance and Takaful. According to The World Takaful Report 2012, Malaysia has a relatively high ratio of average gross written contributions per operator. The 14 operators in Malaysia grew their contributions by an average of US\$20m in 2010 .

\section{Efforts towards full Shari'ah compliance in Takaful industry in Malaysia}

Regulations from the Islamic finance standards setting bodies (i.e. AAOIFI \& IFSB) and the global accounting reporting standards from IASB and IFRS need greater convergence. This standardization will make it easier for market regulators to provide a framework to regulate the Takaful operators. As the industry continues to grow and develop, market regulators and the two bodies that set the Islamic finance industry standards, AAOIFI and IFSB, are facing head on the challenges of implementing a successful and effective regulatory framework. Regulators across the world have different objectives and roles to play in their domestic markets. Most have the common goal of protecting consumers and prevention of systemic disruption and this translates into a number of the basic obligations and activities Takaful operators have to comply with.

Malaysia is among the pioneering jurisdictions that have successfully developed and incorporated Islamic finance into its modern financial system. In the Malaysian context, the regulatory part is carried out by Bank Negara Malaysia (BNM) as the highest authority body to regulate and shape the Takaful industry to be a leading country in the world for Takaful products and services. In this regard, BNM has established a strong act and framework beginning with the Takaful Act 1984 (the only one of its kind in the world), which was gazetted on $31^{\text {st }}$ December 1984. This act provides a clear guidance and direction for Takaful operators to conduct their business in accordance to Shari'ah requirements and Malaysian law.

To further promote the orderly growth of Takaful business, the Guidelines on Takaful Operational Framework was issued and came into effect on 1 January 2012 with revisions in June 2013, outlining parameters to govern operational processes of Takaful operators and defining in detail where necessary, the various rules and requirements for Takaful operators without limiting or specifying particular contracts to apply to the Takaful operations. The objectives of the guidelines are as follows:

1. To enhance operational efficiency of Takaful business

2. To build healthy Takaful funds which are sustainable

3. To safeguard the interests of participants

4. To promote uniformity in Takaful business practices.

With this detailed guidance, Malaysia is raising its regulation of Takaful to a new level of sophistication. In the Financial Sector Blueprint 2011 - 2020 issued by BNM, one of the plans and initiatives for the financial stability towards becoming a high-income nation by 2020 is 'Safeguarding the stability of the financial system'. It states that:

"A regulatory and supervisory regime - that effectively maintains the stability of the financial system and soundness of financial institutions is necessary for sustainable growth and the orderly development of the financial sector. Significant attention has been directed over the recent decade towards strengthening the effectiveness of the regulatory regime, in line with leading standards and practices, and providing an enhanced focus on governance practices and risk management”.

\section{a. Islamic Financial Services Act (IFSA) 2013}

After almost three decades in enforcement, the Takaful Act 1984 has now been replaced and repelled with the Islamic Financial Services Act 2013 (IFSA). The Parliament of Malaysia has enacted the IFSA and it was 
published in the Gazette on 22 March 2013. The IFSA will replace two existing Acts which are Islamic Banking Act 1983 and Takaful Act 1984. The objectives of the enactment of this act are to:

i. Introduce a more risk-focused and integrated approach to the regulation and supervision of financial institutions (FI) to safeguard financial stability.

ii. Provide a comprehensive Shari'ah-compliant legal framework in all aspects of regulation and supervision.

iii. Ensure effective functioning of money market, foreign exchange market, payment systems, and payment instruments.

iv. Strengthen consumer protection in financial products and services.

The enactment of IFSA is in line with BNM's Financial Sector (FS) Blueprint 2011-2020 aimed at strengthening the regulatory and supervisory regime of Malaysia's financial sector. It has a significant impact on Takaful operators in the industry as a whole. There are five (5) takeaway impacts to Takaful operators and they can be summarized as follows:

1. Requirement - Insurance and Takaful companies holding composite licenses shall not carry on both life insurance/family Takaful business and general insurance/general Takaful business.

2. Who will be impacted? - Licensed insurer/Takaful operator lawfully carrying on both life insurance/family Takaful business and general insurance/general Takaful business.

3. Who will be exempted? - Licensed professional reinsurer and retakaful operator.

4. Timeline - 5 years from the date of implementation of the Act(s) or longer as specified by the Minister of Finance, on the recommendation of BNM.

5. Non-compliance penalty - Imprisonment of 8 years or less or a fine of RM25 million or less or both.

It involves codification of duty on Islamic financial institutions to ensure its aims, operations, business, affairs, and activities are in compliance with Shari'ah at all times:

- Compliance with rulings of Shari'ah Advisory Council is a determinant of "compliance with Shari'ah"

- Reporting obligations on non-Shari'ah compliances imposed on Islamic financial institutions

- Bank empowered to assess rectification plan to address non-compliances

- Backed by comprehensive enforcement tools to address non-compliances

There are 281 clauses in FSA and 291 clauses in IFSA. The extracted as listed below are only five (5) highlighted clauses which relate to Takaful:

1. Conversion to single insurance/Takaful business - A licensed insurer/Takaful operator, other than a licensed professional reinsurer/retakaful operator, shall not carry on both life insurance/family Takaful business and general insurance/general Takaful business. FSA 16 (1)/IFSA 16 (1)

2. Reporting obligations - Auditor shall report to the Bank if there is any breach, fraud, irregularities, non-compliance, weakness in internal controls or material impact of any event, conduct or activity by an institution under the Act(s) in the course of carrying out his duties as an auditor. FSA 72/IFSA 81

3. Limitation on individual shareholdings - Individual shall hold no more than 10 percent of interest in shares of a licensed person. FSA 92/IFSA 104 (1)

4. Financial holding company requirement - Any company which holds an aggregate interest in shares of more than 50 percent in a licensed person shall submit an application to the Bank to be approved as a financial holding company. FSA 110 (1)/IFSA 122 (1) 
5. Power of Minister to prescribe financial institutions - On recommendation by the Bank alone or jointly with the relevant authority, the Minister of Finance may prescribe any person not under the Bank's supervision and engaging in financial intermediation activities as a prescribed financial institution if such person, in the opinion of the Bank, poses or is likely to pose risks to financial stability. FSA 212/IFSA 223

\section{Conclusion}

In conclusion, the merger and acquisition (M\&A) which have taken place recently by other foreign insurers with our local Takaful operators show that the growth of this industry is promising for years to come for the foreign insurers to tap into our Takaful market. This event of M\&A is in line with the government's inspiration and direction to bring in more foreign direct investment (FDI) to boost our economy, especially in the financial services sector and Islamic finance and Takaful specifically. This also shows that our market is capable of generating profit and has great potential to grow in the eye of foreign insurers. Islamic finance in Malaysia will continue to expand, reinforced by the global expansion where creation, preservation and distribution of wealth are effectively undertaken by market participants in a manner that promotes the universal values of Shari'ah principles.

In my opinion, the participation of long established conventional insurance conglomerates will be positive towards the development of the Takaful particularly in the aspect of the operators' compliance towards Shari'ah. Participation of established conventional insurance conglomerates abroad will create a healthy competition among the Takaful operators in producing the best Takaful product to suit the needs of the customers and participants. With regards to the compliance of Shari'ah in their operation, they are bound to the rules and regulations of Takaful operation to adhere to the regulator's requirements to ensure that their operations are in accordance with the Shari'ah at all times. It does not matter whether they are local or foreign insurance conglomerates, once they have a license to offer a Takaful product in our local market, they are bound to fully adhere to the IFSA. This is because the authority has a strict requirement for any insurance conglomerate that wishes to apply for a license to operate in Malaysia. BNM has strong and solid methods in the selection of granting and issuing any license to foreign insurance conglomerate to operate in our local Takaful market.

With a great prospect in growing ahead, we really believe that this industry will grow more rapidly than expected. With the current growth rate and the opportunity from a very low Takaful and insurance penetration rate of Muslim countries, it is viewed as a profitable industry in the future. Despite all its great potential, it is also surrounded with challenges and shortcomings that demand our efforts and focus in improving the industry.

\section{References}

Bank Negara Malaysia (BNM). (2015). Malaysian Takaful Industry 1984-2004. Retrieved from: http://www.bnm.gov.my/files/publication/tkf/en/2004/booklet.en.pdf

Bank Negara Malaysia (BNM). (2015). Islamic Banking \& Takaful. Retrieved from: http://www.bnm.gov.my/index.php?ch=fs_mfs\&pg=fs_mfs_bank\#Takaful.

Bank Negara Malaysia (BNM). (2015). List of Licensed Financial Institutions. Retrieved from: http://www.bnm.gov.my/index.php?ch=fs_mfs\&pg=fs_mfs_list\&lang=en.

Ernst \& Young. (2013). Take 5. Volume 1- Issue 1 -5 April 2013. Retrieved from: http://www.ey.com/Publication/vwLUAssets/Take_5_Volume_1/\$FILE/Take_5_issue1_April_2013.pdf.

Ernst \& Young. (2013). Global Takaful Insights 2013. Retrieved from: http://www.ey.com/Publication/vwLUAssets/ET_Global_Takaful_Insights_2013/\$File/EY-global-takafulinsights-2013.pdf

Ernst \& Young. (2012). The World Takaful Report 2012. Retrieved from: http://uaelaws.files.wordpress.com/2012/04/the-world-takaful-report-2012.pdf 
Hashim, S., Shahidan, A., \& Fadzim, W. R. (2005) The element of gambling in conventional insurance and takaful”. In: Pengukuhan dan transformasi ekonomi \& kewangan Islam prosiding Seminar Ekonomi dan Kewangan Islam, 29 - 30 Ogos 2005. Retrieved from: http://repo.uum.edu.my/1403/1/Suraiya,_Asnida_\%26_Wan_Roshidah[1].pdf Mulhim, S. A. \& Sabbagh, M. A. (2010). The Islamic Insurance: Theory and Practice. Available online at: http://www.albaraka.com/media/pdf/Research-Studies/Book-Islamic-Insurance.pdf.

Malaysia Takaful Association. (2016). About MTA. Retrieved from http://www.malaysiantakaful.com.my/AboutMTA/History-of-MTA.aspx.

http://zulkiflihasan.files.wordpress.com/2008/06/19_guidelines_takaful_operational_framework.pdf.

Islamic Finance News Supplements. May 2012. Available online at: http://www.islamicfinancenews.com/2012_supplement/2012takaful/Takaful.pdf. 